\title{
Does Radiotherapy Have Curative Potential in Metastatic Patients? The Concept of Local Therapy in Oligometastatic Breast Cancer
}

\author{
Kathrin Dellas
}

North European Radiooncological Center Kiel and University of Luebeck, Department of Radiotherapy, Germany

\section{Keywords}

Breast cancer - Oligometastases · Radiotherapy · Stereotactic body radiotherapy, SBRT

\section{Summary}

In 1995, Hellmann and Weichselbaum defined for the first time the term oligometastases which is used to describe limited metastasis with a maximum of 3-4 clinically detectable metastases. It is assumed that these patients have a better prognosis and that local treatment of the metastases plays a significant part in the further development of the disease. Therefore, these patients could benefit from a curative local therapy of the manifested metastases. Local therapy measures include mainly radiotherapeutic methods alongside invasive ablative processes, such as surgical resection and radiofrequency ablation. Patients subjected to radiation therapy benefit especially from the usage of modern precision technology as it reduces the radiation exposure to the normal tissue, and because short radiation sessions with escalating doses are possible (e.g. radiation surgery, image-assisted radiation therapy, stereotactic radiation). Initial clinical studies show very good local tumor control rates which are on a par with resection and ablative methods, but with very few side effects and risks. This article summarizes the integration of the concept of oligometastases in the radiotherapy of limited metastatic breast cancer.

\author{
Schlüsselwörter \\ Mammakarzinom - Oligometastasierung · Radiotherapie · \\ Stereotactic Body Radiotherapy, SBRT
}

\section{Zusammenfassung}

Unter dem von Hellmann und Weichselbaum 1995 erstmals verwendeten Begriff der Oligometastasierung versteht man eine limitierte Metastasierung mit maximal 3-4 klinisch detektierbaren Metastasen. Es wird vermutet, dass diese Patienten eine bessere Prognose haben und dass die lokale Kontrolle der Metastasen für den weiteren Krankheitsverlauf eine Rolle spielt. Diese Patienten könnten daher von einer kurativen lokalen Therapie der manifesten Metastasen profitieren. Als lokale Therapiemaßnahme steht neben der Resektion und invasiven ablativen Verfahren (z.B. Radiofrequenzablation) auch die Radiotherapie zur Verfügung. Bei der Strahlentherapie von Metastasen profitieren Patienten in besonderem Maße vom Einsatz moderner Präzisionstechniken, weil dadurch die Strahlenbelastung des Normalgewebes reduziert wird und Kurzzeitbestrahlungen mit Dosiseskalationen möglich sind (z.B. Strahlenchirurgie, bildgeführte Strahlentherapie, stereotaktische Bestrahlung). Erste klinische Studien zeigen sehr gute lokale Tumorkontrollraten, die der Resektion und den ablativen Verfahren gleichwertig sind, aber sehr wenig Nebenwirkungen und Risiken beinhalten. Der vorliegende Artikel fasst die Integration des Konzeptes der Oligometastasierung in das lokale radiotherapeutische Vorgehen des limitiert metastasierten Mammakarzinoms zusammen.

\section{KARGER \\ Fax +497614520714 \\ Information@Karger.de}

www.karger.com (c) 2011 S. Karger GmbH, Freiburg

1661-3791/11/0065-0363\$38.00/0

Accessible online at:

www.karger.com/brc
Dr. Kathrin Dellas

Nordeuropäisches Radioonkologisches Zentrum Kiel (NRoCK) GmbH

Wall 55 (Sell-Speicher), 24103 Kiel, Germany

Tel. +49 4315973011

Kathrin.Dellas@uksh.de 


\section{Introduction}

Breast cancer is by far the most frequent cancer among women, with an estimated 1.38 million new cancer cases diagnosed in 2008 ( $23 \%$ of all cancers), and it is now the most common cancer both in developed and developing countries. The range of mortality rates is lessened by the more favorable survival of breast cancer in developed regions. As a result, breast cancer ranks as the 5th cause of death from cancer overall (458,000 deaths), but it is still the most frequent cause of cancer death in women in both developing $(269,000$ deaths, $12.7 \%$ of total) and developed regions where the estimated 189,000 deaths is almost equal to the estimated number of deaths from lung cancer (188,000 deaths) [1]. 30-40\% of all patients develop distant metastases during the course of their disease [2], and the number of patients with isolated metastases that are eligible for surgical resection is estimated to be relatively small [3].

\section{Hypotheses about Oligometastases}

For many years, metastatic breast cancer was generally considered as an incurable disease. However, metastatic breast cancer represents very heterogeneously from a solitary metastatic lesion to diffuse and multiple organ involvement. Retrospective analyses of single institution experiences provide evidence that selected patients with an isolated metastatic lesion or few metastases (so-called oligometastases), who are treated with aggressive combined-modality therapy, may remain disease-free over more than a decade without ever developing additional metastatic deposits [4]. It remains unclear whether this is due to a selection of patients with favorable prognostic factors or whether it can be considered as a treatment result. The term oligometastases, literally interpreted as 'few metastases', was introduced by Hellmann and Weichselbaum in 1995 [5]. Oligometastatic disease has been hypothesized as a clinical state in which the full metastatic potential is not reached and local therapy may offer cure in some patients [5-10]. The authors proposed a clinically significant oligometastatic state to be an intermediated form with limited in number and location metastasis, representing an early course in the chain of metastatic progression amendable by application of a curative therapeutic strategy [5] (table 1).

\section{Is Oligometastatic Disease Curable? Lessons from Other Disease Sites}

The hypothesis that local therapy, if added to an effective systemic treatment, may improve survival is supported by findings in another tumor type. In Ewing's sarcoma, the benefits of applying local radiotherapy to metastatic lesions has been convincingly demonstrated; in patients with lung metastases at diagnosis, additional consolidating total lung irradiation was able to increase 5-year survival rates from 20 to $40 \%$ [11, 12]. In patients with metastases confined to the bones, the combination of intensive chemotherapy and radiotherapy of metastatic lesions has yielded promising survival figures in phase I/ II trials. According to preliminary experience in this disease, the addition of local therapy to standard systemic treatment and intensification of local therapy are of equal if not higher value than intensification of chemotherapy [12-14].

The positive effect of additional local therapy to metastatic lesions has also been evaluated in colorectal cancer. At the time of diagnosis, about $25 \%$ of patients present with metastases, and more than one third of patients will develop metastatic disease after curative resection of the primary tumor in the further course of the disease, mainly liver metastases. Patients with a single or few liver or lung metastases should

\begin{tabular}{|c|c|c|c|c|}
\hline & Early disease & $\begin{array}{l}\text { Locally advanced } \\
\text { disease }\end{array}$ & Oligometastatic disease & Metastatic disease \\
\hline Disease extend & $\begin{array}{l}\text { small primary tumor, } \\
\text { no lymph node } \\
\text { metastases }\end{array}$ & $\begin{array}{l}\text { large primary tumor, } \\
\text { lymph node metastases }\end{array}$ & $\begin{array}{l}\text { solitary or few } \\
\text { metastatic lesions }\end{array}$ & $\begin{array}{l}\text { multiple organ } \\
\text { involvement }\end{array}$ \\
\hline Chance of cure & high $(90 \%)$ & medium $(50 \%)$ & zero? & zero \\
\hline Treatment intent & curative & curative & curative? & palliative \\
\hline Type of treatment & $\begin{array}{l}\text { locoregional } \\
+ \text { adjuvant systemic }\end{array}$ & $\begin{array}{l}\text { locoregional } \\
+ \text { adjuvant systemic }\end{array}$ & systemic + local? & systemic \\
\hline
\end{tabular}

Table 1.

Oligometastatic disease representing a specific condition between locally confined curable disease and incurable metastatic disease

Table 2. Theoretical concept of combining systemic and local therapies in oligometastatic cancer

\begin{tabular}{ll}
\hline Diagnostics & $\begin{array}{l}\text { The tumor load must be determined as precisely as possible (computed tomography, magnetic resonance imaging, } \\
\text { positron emission tomography etc.) to exclude disseminated disease and exactly define the targets of local therapy. }\end{array}$ \\
$\begin{array}{ll}\text { Systemic control and therapy } & \text { It is anticipated that the disease can be systemically be controlled. Occurrence of new lesions is unlikely. } \\
& \text { Control of visible lesions will impact on the further course of disease. } \\
\text { Local therapy } & \text { Effective local therapy with minimal side effects is available. } \\
\text { Multimodal treatment concept } & \text { Systemic and local therapy can be combined without hindering each other. }\end{array}$ \\
\hline
\end{tabular}


undergo curative-intent resection of their metastases, with a resulting chance of long-term cure in the range of 30-40\% [15]. In 1986, Hughes et al. [16] published a multi-institutional trial of 607 patients who had received curative resection for liver metastasis from colorectal cancer with $25 \%$ of patients disease-free at 5 years, whereas in 1996, Nordlinger et al. [17] reported 1,568 patients who underwent liver resection for metastasis with a 5 -year survival rate of $28 \%$. In unresectable disease, palliative chemotherapy aims to prolong survival while preserving or improving quality of life. In the past, the border between a potentially curative and a palliative approach was therefore mainly determined by resectability.

Table 3. Prognostic parameters in patients treated with high-dose chemotherapy for relapsed breast cancer \pm local therapy to metastatic sites showing irradiation of metastatic lesions to be the only relevant therapy-related parameter (relapse-free interval, type of adjuvant treatment, pharmacokinetics of high-dose chemotherapy not significant [20])

\begin{tabular}{|c|c|c|}
\hline & $\begin{array}{l}\text { Relapse-free } \\
\text { survival, \% }\end{array}$ & $\mathrm{p}^{\mathrm{a}}$ \\
\hline Her-2 status & & 0.003 \\
\hline Negative & 71 & \\
\hline Positive & 27 & \\
\hline Initial nodal status & & 0.01 \\
\hline $1-3$ & 74 & \\
\hline$>3$ & 36 & \\
\hline Radiotherapy of metastatic lesions & & 0.01 \\
\hline Yes & 63 & \\
\hline No & 18 & \\
\hline Hormone receptor status & & 0.02 \\
\hline Positive & 62 & \\
\hline Negative & 33 & \\
\hline Category of primary tumor & & 0.02 \\
\hline pT1 & 73 & \\
\hline pT2 & 52 & \\
\hline pT3 & 64 & \\
\hline pT4 & 0 & \\
\hline Number of metastatic lesions & & 0.03 \\
\hline 1 & 63 & \\
\hline$>1$ & 29 & \\
\hline Site of metastatic lesions & & 0.11 \\
\hline Local & 67 & \\
\hline Distant & 59 & \\
\hline Both & 27 & \\
\hline Surgery of metastatic lesions & & 0.73 \\
\hline Yes & 56 & \\
\hline No & 52 & \\
\hline
\end{tabular}

Table 4. Impact of locoregional treatment on survival in patients with primarily metastatic breast cancer [48]

\begin{tabular}{llll}
\hline & $\begin{array}{l}\text { Systemic } \\
\text { therapy alone }\end{array}$ & $\begin{array}{l}\text { Systemic ther- } \\
\text { apy plus LRT }\end{array}$ & p \\
\hline Total, n & 261 & 320 & \\
Type of LRT, n (\%) & $(26.7)$ & $249(78)$ & \\
$\quad$ Radiotherapy alone & $41(13)$ & 0.0002 \\
$\quad \begin{array}{lll}\text { Surgery + radiotherapy } \\
\text { Surgery alone }\end{array}$ & $30(9)$ & \\
3-year overall survival, \% & 43.4 & \\
\hline LRT = Locoregional therapy. & & \\
\hline
\end{tabular}

Radiotherapy for Oligometastatic

Breast Cancer
Recently, a variety of non-surgical local ablative therapies, especially stereotactic radiotherapy or radiofrequency ablation, have been developed, and the question has arisen whether a subset of patients with a limited number of metastases might benefit from the addition of such local treatment. From a theoretical point of view, this concept requires a multimodal diagnostic and therapeutic strategy based on the individual course of disease (table 2).

\section{Molecular Investigations of Oligometastases}

Investigations of the molecular biology of oligometastases are very limited. Cillo et al. [18] described that clones with high metastatic potential were more resistant to chemotherapy than cells derived from clones of low metastatic potential. Furthermore, Khodarev et al. [19] used the B16F1 mouse melanoma model and reported that repeated passage through the lungs evolved a more 'aggressive' phenotype defined by increased efficiency in lung colonization and resistance to radiotherapy and chemotherapy of the more highly metastatic clones [7].

\section{Local Therapy in Metastatic Breast Cancer}

Treatment concepts in breast cancer have over the past decades been dominated by the hypothesis that breast cancer behaves always like a systemic disease. In the past years, however, it has been clearly demonstrated that improvement of local control impacts on survival in locoregionally confined disease. Results from a variety of retrospective investigations suggest that even in breast cancer the addition of local therapy (especially radiation therapy) to metastatic sites may be associated with better survival [20, 21]. In the analysis by Nieto et al. [20], the addition of radiotherapy to metastatic lesions was the only therapy-related prognostic factor in patients undergoing intensive chemotherapy for relapsed breast cancer (table 3). Moreover, a retrospective investigation has recently shown that addition of locoregional treatment to systemic therapy improved survival in patients with advanced locoregional disease and metastases at diagnosis. This study found that radiotherapy as locoregional treatment was effective in combination with surgery and also if administered exclusively without surgery (table 4). Moreover, patients with oligometastases, who achieve long-term local control after palliative irradiation to metastatic sites, seem to have prolonged survival times [22]. Nevertheless, an additional systemic treatment would possibly be necessary, $73 \%$ of patients with oligometastatic breast cancer developed further sites [23]. In summary, these findings have challenged the dogma that metastatic breast cancer is always incurable and have raised the question whether selected patients with limited metastases may be cured [24]. 


\section{Local Treatment Options in Oligometastatic Breast Cancer}

Surgical resection is surely a potentially curative treatment in patients with single metastases of breast cancer [3]. More recently, however, the use of radiotherapy including stereotactic radiotherapy and radiofrequency ablation offers a less invasive approach and could provide a potentially curative treatment of oligometastases [25-31]. Data from recent prospective trials demonstrate that high-precision radiotherapy techniques provide local control rates which are at least comparable to resection $[30,31]$.

\section{Combining Irradiation and Systemic Therapy}

In patients with locally advanced breast cancer, best results are achieved by combining local radiation and systemic therapy [24, 32]. Although some in vitro experiments [32-34] demonstrated a decreased sensitivity to ionizing radiation after incubation of MCF-7 cell lines with tamoxifen, an antagonistic effect of ionizing radiation and treatment with tamoxifen has not been confirmed in animal studies [35, 36]. In contrast, several large randomized clinical studies [37] comparing adjuvant tamoxifen, radiation therapy and placebo, and combined radiation therapy and tamoxifen demonstrated best results [38]. Thus, the experimental endpoints of the in vitro studies may not have been relevant for the in vivo situation, and there is no clinical data for an adverse effect of combined tamoxifen and radiation. Instead, the clinical data argue for a synergistic effect.

\section{Radiotherapy}

3D conformal radiotherapy is now widely available and clearly indicated as standard treatment in patients undergoing radiotherapy for oligometastatic disease [5, 39-41]. The benefit of these techniques is substantial in metastatic disease because the target volume includes only the metastatic lesions without any need for adjuvant irradiation of large normal tissue volumes. This leads to a significant reduction in the radiation dose delivered to the surrounding healthy tissue (fig. 1), which tends to be dose-limiting and preclude application of potentially curative doses as well as concomitant radiosensitizing chemotherapy, and allows safe delivery of curative doses even in intense systemic regimens. More recent techniques with increased precision for treatment set-up und delivery are sparing stereotactic radiotherapy techniques and image-guided radiotherapy (IGRT). Stereotactic techniques use an external coordinate system for treatment set-up. This technique has been well established for brain metastases and is now also used for treatment of extracranial lesions (stereotactic body radiotherapy, SBRT). As a result of the precise

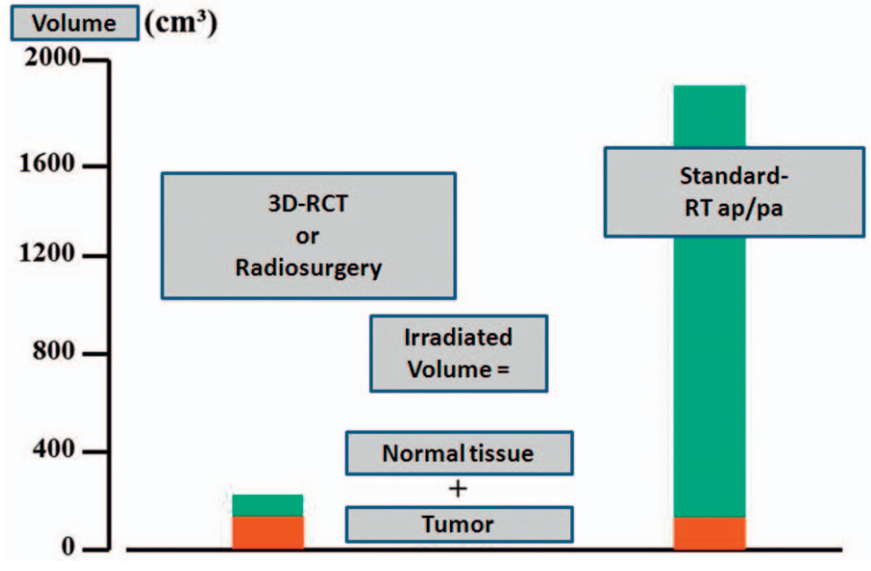

Fig. 1. Impact of 3D conformal radiotherapy (RCT) versus 'older' techniques on normal tissue radiation dose. In patients with 3 target volumes (e.g. 3 metastatic lesions), the gross tumor volume lies in the range of $100-150 \mathrm{~cm}^{3}$. If simple treatment techniques are used (e.g. anterior-posterior opposing portals), a large amount of normal tissue receives the target dose. If conformal treatment techniques are used, the volume of irradiated normal tissue, and hence the risk of acute (and late) side effects, can be dramatically decreased.

treatment set-up, high single doses per fraction (so-called radiosurgery) or hypofractionated regimens can be used. All recent series show promising local tumor control rates in the range of $80-90 \%$ [42-44]. The prospective evaluation of SBRT as a therapy approach for liver and lung metastases of different primary cancers including breast cancer was the aim of 3 investigations by Rusthoven et al. [30, 31] and Lee et al. [27]. In a multi-institutional phase I/II trial of SBRT in 47 patients with any primary tumor ( 4 breast cancer patients) and 1-3 liver metastases, patients received 36-60 Gy in a dose escalating scheme. 63 lesions were treated, mostly smaller than $3 \mathrm{~cm}$ in diameter. Rusthoven et al. [30] reported an excellent 2-year rate of local control (92\%) and for lesions $3 \mathrm{~cm}$ or less an outstanding 2-year rate of local control of $100 \%$. Grade 3 and higher toxicity occurred in only $2 \%$ of the patients [30]. In a second multi-institutional phase I/II trial of SBRT, Rusthoven et al. [31] focused on lung metastases of varying primary origin ( 2 breast cancer patients). In this trial, the authors treated 38 patients with 1-3 lung metastases smaller than $7 \mathrm{~cm}$ with $48-60$ Gy in a dose-escalating scheme. Local control at 1 and 2 years after SBRT was $100 \%$ and $96 \%$, respectively. The poor overall survival (median 19 months) was associated with multiple criteria of unfavorable prognosis; the incidence of grade 3 toxicity was $8 \%$. The phase I study of individualized SBRT of liver metastases by Lee et al. [27] included 68 patients (12 breast cancer patients) with significantly larger liver lesions compared to other trials. The median SBRT dose was 41.8 Gy (range 27.7-60 Gy); the individualized radiation dose was based on the nominal risk of radiation-induced liver disease for 3 estimated risk levels (5, 10 , and $15 \%)$. The 12 -month local control rate was $71 \%$, the 
median survival rate 17.6 months. In a prospective pilot study, Milano et al. [45] analyzed curative-intent SBRT in patients with 5 or less oligometastatic lesions. 121 patients (39 breast cancer patients) with $\leq 5$ detectable metastases were enrolled and treated with 10 fractions of $5 \mathrm{~Gy}$. The 2-year and 4-year patient local control rates were 67 and $60 \%$, respectively. The 2 -year overall survival, progression-free survival, and distant control rates were 50,26 , and $34 \%$, respectively; the respective 4-year rate values were 28,20 , and $25 \%$. A further study conducted by Milano et al. [46] for oligometastatic breast cancer patients with $\leq 5$ metastatic lesions treated with curative-intent SBRT led to a 2-year and 4-year local control of $80 \%$, progression-free survival of $38 \%$, and overall survival of $59 \%$. Milano et al. [47] also analyzed the effects of gross tumor volume and primary cancer site. In this analysis, a greater net tumor volume was predictive of significantly worse survival and disease control, whereas breast cancer as the primary lesion was a favorable predictor of survival and disease control.

\section{Conclusions}

The role of radiotherapy in metastatic disease has evolved from palliative to potentially curative intent for truly localized oligometastases. For these reasons, enhancing local control of metastatic lesions by means of 3D conformal radiotherapy (with concomitant application of systemic therapy) is a promising strategy for patients with oligometastatic breast cancer. In the last decade, different patterns of highly conformal radiotherapy (SBRT, IGRT, radiosurgery) emerged as potentially curative therapeutic strategies for localized lesions. Introduction of SBRT to multimodal treatment led to excellent response rates and local control rates of up to 2 years. Its effects on progression-free and overall survival are still pending questions especially in comparison with resection or ablative approaches such as radiofrequency ablation. It raises the questions of whether we can truly reach ablation by use of (stereotactic body) radiotherapy, and whether we can cure the subgroup of patients with oligometastases. Breast cancer patients can have a prolonged course of disease, but further studies are needed to assess the impact of different methods of radiotherapy as curative-intent local therapy for patients with truly limited metastatic breast cancer.

\section{Disclosure Statement}

The author declares no conflict of interest.

\section{References}

1 IARC (International Agency for Research on Cancer), Globocan 2008: www.dep.iarc.fr/globocan/globocan.html.

2 O'Shaughnessy J, Miles D, Vukelja S, Moiseyenko V, Ayoub JP, Cervantes G, Fumoleau P, Jones S, Lui WY, Mauriac L, Twelves C, Van Hazel G, Verma S, Leonard R: Superior survival with capecitabine plus docetaxel combination therapy in anthracycline-pretreated patients with advanced breast cancer: phase III trial results. J Clin Oncol 2002;20:2812-23.

3 Singletary SE, Walsh G, Vauthey JN, Curley S, Sawaya R, Weber KL, Meric F, Hortobágyi GN: A role for curative surgery in the treatment of selected patients with metastatic breast cancer. Oncologist 2003:8:241-51.

4 Holmes FA, Buzdar AU, Kau S-W, Fraschini G, Ames FC, McNeese MD, et al.: Combined-modality approach for patients with isolated recurrences of breast cancer (IV-NED) - the M. D. Anderson experience. Breast Dis 1994;7:7-20.

$\checkmark 5$ Hellman S, Weichselbaum RR: Oligometastases. J Clin Oncol 1995;13:8-10.

6 Hellman S, Weichselbaum RR: Importance of local control in an era of systemic therapy. Nat Clin Pract Oncol 2005;2:60-61.

7 Weichselbaum RR, Hellman S: Oligometastases revisited. Nat Rev Clin Oncol 2011;8:378-82.

$\checkmark 8$ Milano MT, Zhang H, Metcalfe SK, Muhs AG, Okunieff P: Oligometastatic breast cancer treated with curative-intent stereotactic body radiation therapy. Breast Cancer Res Treat 2009;115:601-8.
9 Koong AC, Le QT, Ho A, Fong B, Fisher G, Cho C, Ford J, Poen J, Gibbs IC, Mehta VK, Kee S, Trueblood W, Yang G, Bastidas JA: Phase I study of stereotactic radiosurgery in patients with locally advanced pancreatic cancer. Int $\mathrm{J}$ Radiat Oncol Biol Phys 2004;58:1017-21.

10 Tait CR, Waterworth A, Loncaster J, Horgan K, Dodwell D: The oligometastatic state in breast cancer: hypothesis or reality. Breast 2005;14:87-93.

11 Dunst J, Paulussen M, Juergens H: Lung irradiation for Ewing's sarcoma with pulmonary metastases at diagnosis: results of the CESS-studies. Strahlenther Onkol 1993;169:621-3.

12 Paulussen M, Ahrens S, Craft AW, Dunst J, Fröhlich B, Jabar S, Rübe C, Winkelmann W, Wissing S, Zoubek A, Jürgens H: Ewing's tumors with primary lung metastases: survival analysis of 114 (European Intergroup) Cooperative Ewing's Sarcoma Studies patients. J Clin Oncol 1998; 16:3044-52.

13 Burdach S, van Kaick B, Laws HJ, Ahrens S, Haase R, Körholz D, Pape H, Dunst J, Kahn T, Willers R, Engel B, Dirksen U, Kramm C, Nürnberger W, Heyll A, Ladenstein R, Gadner H, Jürgens H, Go el U: Allogenic and autologous stem-cell transplantation in advanced Ewing tumors. An update after long-term follow-up from two centers of the European Intergroup study EICESS. Stem-Cell Transplant Programs at Düsseldorf University Medical Center, Germany and St. Anna Kinderspital, Vienna, Austria. Ann Oncol 2000;11:1451-62.
14 Meyers PA, Krailo MD, Ladanyi M, Chan KW Sailer SL, Dickman PS, Baker DL, Davis JH, Gerbing RB, Grovas A, Herzog CE, Lindsley KL, Liu-Mares W, Nachman JB, Sieger L, Wadman J, Gorlick RG: High-dose melphalan, etoposide, total-body irradiation, and autologous stem-cell reconstitution as consolidation therapy for highrisk Ewing's sarcoma does not improve prognosis. J Clin Oncol 2001;19:2812-20.

15 Tomlinson JS, Jarnagin WR, DeMatteo RP, Fong Y, Kornprat P, Gonen M, Kemeny N, Brennan MF, Blumgart LH, D'Angelica M: Actual 10-year survival after resection of colorectal liver metastases defines cure. J Clin Oncol 2007;25:4575-80.

16 Hughes KS, Simon R, Songhorabodi S, Adson MA, Ilstrup DM, Fortner JG, Maclean BJ, Foster JH, Daly JM, Fitzherbert D, et al.: Resection of the liver for colorectal carcinoma metastases: a multiinstitutional study of patterns of recurrence. Surgery 1986;100:278-84.

17 Nordlinger B, Guiguet M, Vaillant JC, Balladur P, Boudjema K, Bachellier P, Jaeck D: Surgical resection of colorectal carcinoma metastases to the liver. A prognostic scoring system to improve case selection, based on 1568 patients. Association Française de Chirurgie. Cancer 1996;77:1254-62.

18 Cillo C, Dick JE, Ling V, Hill RP: Generation of drug-resistant variants in metastatic B16 mouse melanoma cell lines. Cancer Res 1987;47:2604-8.

19 Khodarev NN, Roach P, Pitroda SP, Golden DW, Bhayani M, Shao MY, Darga TE, Beveridge MG, Sood RF, Sutton HG, Beckett MA, Mauceri HJ, Posner MC, Weichselbaum RR: STAT1 pathway mediates amplification of metastatic potential and resistance to therapy. PLoS One 2009;4:e5821. 
20 Nieto Y, Nawaz S, Jones RB, Shpall EJ, Cagnoni PJ, McSweeney PA, Barón A, Razook C, Matthes S, Bearman SI: Prognostic model for relapse after high-dose chemotherapy with autologous stem-cell transplantation for stage IV oligometastatic breast cancer. J Clin Oncol 2002;20:707-18.

-21 Bojko P, Welt A, Schleucher R, Borquez D, Scheulen ME, Vanhoefer U, Poettgen C, Stuschke M, Broelsch CE, Stamatis G, Wilke H, Seeber S, Harstrick A: High-dose chemotherapy with autologous stem cell transplantation in patients with oligometastatic breast cancer. Bone Marrow Transplant 2004;34:637-43.

22 Rades D, Fischer D, Veninga T, Stalpers LJ, Schild SE: Prognostic factors for survival and intracerebral control after irradiation for brain metastases from gynecological cancer. Gynecol Oncol 2009;114:506-8.

23 Milano MT, Katz AW, Okunieff P: Patterns of recurrence after curative-intent radiation for oligometastases confined to one organ. Am J Clin Oncol 2010;33:157-63.

24 Hortobagyi G, Piccart-Gebhart MJ: Current management of advanced breast cancer. Semin Oncol 1996;23(suppl 11):1-6.

25 Ben-Josef E, Lawrence TS: Using a bigger hammer: the role of stereotactic body radiotherapy in the management of oligometastases. J Clin Oncol 2009;27:1537-9.

-26 Salama JK, Stenson KM, List MA, Mell LK, Maccracken E, Cohen EE, Blair E, Vokes EE, Haraf DJ: An initial report of a radiation doseescalation trial in patients with one to five sites of metastatic disease. Clin Cancer Res 2008;14:5255-9.

-27 Lee MT, Kim JJ, Dinniwell R, Brierley J, Lockwood $\mathrm{G}$, Wong $\mathrm{R}$, Cummings $\mathrm{B}$, Ringash $\mathrm{J}$, Tse RV, Knox JJ, Dawson LA: Phase I study of individualized stereotactic body radiotherapy of liver metastases. J Clin Oncol 2009;27:1585-91.

28 Macdermed, DM, Weichselbaum, RR and Salama, JK: A rationale for the targeted treatment of oligometastases with radiotherapy. J Surg Oncol 2008;98:202-6. Review.

29 Fakiris AJ, McGarry RC, Yiannoutsos CT, Papiez L, Williams M, Henderson MA, Timmerman R Stereotactic body radiation therapy for early-stage non-small cell lung carcinoma: four-year results of a prospective phase II study. Int J Radiat Oncol Biol Phys 2009;75:677-82.
30 Rusthoven KE, Kavanagh BD, Cardenes H, Stieber VW, Burri SH, Feigenberg SJ, Chidel MA, Pugh TJ, Franklin W, Kane M, Gaspar LE, Schefter TE: Multi-institutional phase I/II trial of stereotactic body radiation therapy for liver metastases. J Clin Oncol 2009;27:1572-8.

31 Rusthoven KE, Kavanagh BD, Burri SH, Chen C, Cardenes H, Chidel MA, Pugh TJ, Kane M, Gaspar LE, Schefter TE: Multi-institutional phase I/II trial of stereotactic body radiation therapy for lung metastases. J Clin Oncol 2009;27:1579-84.

32 Brito RA, Valero V, Buzdar AU, Booser DJ, Ames F, Strom E, Ross M, Theriault RL, Frye D, Kau SW, Asmar L, McNeese M, Singletary SE, Hortobagyi GN: Long-term results of combined modality therapy for locally advanced breast cancer with ipsilateral supraclavicular metastases: The University of Texas M.D. Anderson Cancer Center experience. J Clin Oncol 2001;19:628-33.

33 Wazer DE, Tercilla OF, Lin PS, Schmidt-Ullrich RK: Modulation in the radiosensitivity of MCF-7 human breast carcinoma cells by $17 \mathrm{~b}$-estradiol and tamoxifen. Br J Radiol 1989;62:1079-83.

34 Paulsen GH, Strickert T, Marthinsen AB, Lundgren S: Changes in radiation sensitivity and steroid receptor content induced by hormonal agents and ionizing radiation in breast cancer cells in vitro. Acta Oncol 1996;35:1011-9.

35 Kantorowitz DA, Thompson HJ, Furmanski P: Effect of conjoint administration of tamoxifen and high-dose radiation on the development of mammary carcinoma. Int J Radiat Oncol Biol Phys 1993;26:89-94.

36 Inano H, Onoda M, Suzuki K, Kobayashi H, Wakabayashi K: Prevention of radiation induced mammary tumours in rats by combined use ofWR-2721 and tamoxifen. Int J Radiat Biol 2000;76:1113-20.

37 Fisher B, Bryant J, Dignam JJ, Wickerham DL, Mamounas EP, Fisher ER, Margolese RG, Nesbitt L, Paik S, Pisansky TM, Wolmark N; National Surgical Adjuvant Breast and Bowel Project: Tamoxifen, radiation therapy, or both for prevention of ipsilateral breast tumor recurrence after lumpectomy in women with invasive breast cancers of one centimeter or less. J Clin Oncol 2002;20:4141-9.
38 Schmidberger H, Hermann RM, Hess CF, Emons $\mathrm{G}$ : Interactions between radiation and endocrine therapy in breast cancer. Endocr Relat Cancer 2003;10:375-88.

39 Lichtor AS: Three-dimensional conformal radiation therapy: a testable hypothesis. Int J Radiat Oncol Biol Phys 1991;21:853.

40 Leibel SA, Zelefsky MJ, Kutcher GJ, Burman CM, Mohan R, Mageras GS, Ling CC, Fuks Z: Threedimensional conformal radiation therapy in locally advanced carcinoma of the prostate: preliminary results of a phase 1 dose escalation study. Semin Oncol 1994;21:580-97. Review.

41 Vijayakumar S, Myrianthopoulos LC, Rosenberg I, Halpern HJ, Low N, Chen GT: Optimization of radical radiotherapy with Beam's eye view techniques for non-small cell lung cancer. Int J Radiat Oncol Biol Phys 1991;21:779-88.

42 Carey Sampson M, Katz A, Constine LS: Stereotactic body radiation therapy for extracranial oligometastases: does the sword have a double edge? Semin Radiat Oncol 2006;16:67-76.

43 Kavanagh BD, McGarry RC, Timmerman RD Extracranial radiosurgery (stereotactic body radiation therapy) for oligometastases. Semin Radiat Oncol 2006;16:77-84.

44 Timmerman RD, Kavanagh BD, Cho LC, Papiez L, Xing L: Stereotactic body radiation therapy in multiple organ sites. J Clin Oncol 2007;25:947-952.

45 Milano MT, Katz AW, Muhs AG, Philip A, Buchholz DJ, Schell MC, Okunieff P: A prospective pilot study of curative-intent stereotactic body radiation therapy in patients with 5 or fewer oligometastatic lesions. Cancer 2008;112:650-8.

46 Milano MT, Zhang H, Metcalfe SK, Muhs AG, Okunieff P: Oligometastatic breast cancer treated with curative-intent stereotactic body radiation therapy. Breast Cancer Res Treat 2009;115:601-8.

47 Milano MT, Katz AW, Schell MC, Philip A, Okunieff P: Descriptive analysis of oligometastatic lesions treated with curative-intent stereotactic body radiotherapy. Int J Radiat Oncol Biol Phys 2008;72:1516-22.

48 Le Scodan R, Stevens D, Brain E, Floiras JL, Cohen-Solal C, De La Lande B, Tubiana-Hulin M, Yacoub S, Gutierrez M, Ali D, Gardner M, Moisson P, Villette S, Lerebours F, Munck JN, Labib A: Breast cancer with synchronous metastases: survival impact of exclusive locoregional radiotherapy. J Clin Oncol 2009;27:1375-81. 